\title{
The Effects of Projects Based Chemistry Learning Model Assisted by Chemsong Video to Students Learning Completeness and Creativity
}

\author{
Indang Retno Fourniyati ${ }^{1 凶}$, Murbangun Nuswowati $^{2}$, Edy Cahyono $^{3}$ \\ ${ }^{1}$ State Vocational High School 8 Semarang, Indonesia \\ ${ }^{2}$ Chemistry Education, Mathematics and Natural Sciences Faculty, Universitas Negeri Semarang, Indonesia \\ ${ }^{3}$ Chemistry, Mathematics and Natural Sciences Faculty, Universitas Negeri Semarang, Indonesia
}

\begin{tabular}{|c|c|}
\hline Article Info & bstract \\
\hline Published December 2020 & \multirow{3}{*}{$\begin{array}{l}\text { This research aims to examine the effect of project-based chemistry learning } \\
\text { models on cearning completeness and student creativity through the } \\
\text { Chemsong video making project. The research method uses the pretest- } \\
\text { posttest control group design while the data analysis uses the parametric } \\
\text { statistical test that is } \mathrm{N} \text {-gain, the independent sample t test and the sample } \mathrm{t} \text { - } \\
\text { test paired test. The sample in this research was obtained by cluster random } \\
\text { sampling technique from the population of all students of SMK } \mathrm{N} 8 \text {. The gain } \\
\text { normality test showed that the average results of the pretest-posttest clasical } \\
\text { learning completeness increased by } 0.53 \text { with the criteria being in the } \\
\text { experimental class and the control class at } 0,31 \text { with moderate criteria. The } \\
\text { results of the independent sample t-test showed that there was a significant } \\
\text { difference in the classical learning completeness of the experimental and } \\
\text { control group students, which was } 4.56 \text { greater than } t \text { critic } 1.98 \text { with a } \\
\text { significance level of } 5 \% \text {. In the paired sample } t \text { test, the value of sig. ( } 2 \text {-tailed) } \\
\text { of } 0,000<0.05 \text {. Whereas the results of student creativity t-test obtained sig } \\
\text { values. (2-tailed) of } 0,000<0.05 \text {. So it can be concluded that the application } \\
\text { of the chemistry learning model based on the Chemsong video project has an } \\
\text { effect on improving student mastery learning and creativity. }\end{array}$} \\
\hline Creativity & \\
\hline & \\
\hline
\end{tabular}

C 2020 Universitas Negeri Semarang

$\triangle$ correspondence :

State Vocational High School 8 Semarang

p-ISSN 2252-6412

Jalan Pandanaran 2 No.12, Mugassari, Kecamatan Semarang

e-ISSN 2502-4523

Selatan, Kota Semarang, Jawa Tengah, Indonesia 50249

E-mail: indangretno@yahoo.com 


\section{INTRODUCTION}

Learning outcomes are the results of measurements and assessments of business and learning processes. Student learning outcomes are determined by the quality of learning in the classroom, the basic abilities of students, and the learning environment of students. Three main factors affect learning outcomes, namely cognitive ability, achievement motivation, and quality of learning. In line with learning outcomes, creativity in the 21st century has an important role to improve the quality of education in all fields of learning including science, technology, engineering and mathematic (Wahida, 2015). Creativity is also one of the important components in contextual learning in order to be able to successfully face a complex world. Student learning is contextual, can train critical thinking, mastering technology, cooperating, and collaborating is very necessary in solving problems. Creativity is the result of interactions between individuals and their environment (Munandar, 2014). Creativity is one of the 21st century skills needed by students in facing technological advancements and their future career preparation (Bell, 2010; Hanif et al., 2019). Creativity can be defined as a set of strong mental activity abilities to generate or recognize ideas, alternatives, or possibilities that might be useful in solving problems, communicating with others, and entertaining ourselves and others (Al-Oweidi, 2013). With the ability to think creatively students are able to build their knowledge through the ability to observe, ask, analyze and produce a pretty good analysis (Dariman, 2019).

Creativity is very important to each individual to overcome various difficulties, to find a way out of all problems and to achieve their dreams. The importance of creativity in teaching has been expressed Lou et al. (2012) That creativity and social activity can improve learning performance by using Project-based learning (PjBL). The research on creativity is also done by Lou et al. (2012) by designing creative projectbased learning that can enhance student achievement in creativity, and foster the creative ability of students to think independently and in innovation. This Model can effectively increase the effect of students' learning, improve the creativity of students and achieve the strength of students because creativity is able to develop skills in linking ideas, seeing similarities and differences as well as flexibility in retrieval Decision of Knowledge (Munakata \& Vaidya, 2013). In addition to the discussion of Lou et al. (2012), Andyawati (2011) found that creativity can affect the ability to contextualize the problem of contextual learning. The higher the creativity, the higher the ability to solve problems is (Hidayah et a1., 2015). Ardianti et al. (2017) also concluded project-based learning was able to increase student creativity.

Project-based learning is one of the types of learning that organizes students to build their knowledge independently through investigation and discussion to solve problems to achieve their planned targets (Tseng et al., 2013; Sari et al., 2017). Project-based learning involves an authentic learning environment that allows students to build knowledge in an authentic context (Ardianti et al., 2017). Such learning is believed to be the best approach that can facilitate learners to have complete control over their learning process (Jumaat \& Tasir, 2013). Project Based Learning is one of the constructivism approaches in which cooperation between students finds and builds their knowledge through active learning (Sumarni, 2013). The project-based learning process is based on research, design, and everything involving the activity of the mind and activity of students directly (Hsieh et al., 2013).

Based on conceptual studies, more research needs to be conducted on the effectiveness of the project-based learning model of Chemsong assisted video in enhancing the creativity of vocational students on chemical learning. The research aims to describe and review the effectiveness of the project-based chemical learning model to enhance student creativity through the project of vocational video production of SMK students.

\section{METHODS}

This research is a quasi-experimental study using a control group pretest posttest design as the design of this study. In this study, researchers used the control group as a reference group and the experimental group as a group to be given 
treatment. In the control group learning is given with conventional learning and the experimental group is given learning by using a project-based learning model supported by Chemsong video.

The population used in this study were students of class X SMK N 8 Semarang in the $2019 / 2020$ academic year. Sampling in this study using the technique of clusster random sampling and the samples used were students of class $\mathrm{X}$ TKJ 1, X TKJ 2 and X TKJ 3 which were assumed to be homogeneous and normal. The independent variable of this study is the learning model used is a project-based learning model that is supported by Chemsong video and a conventional learning model that is usually done by the teacher. The dependent variable used in the study was student completeness and student creativity in learning chemistry. The data taken in the research conducted was data on students' creativity with observation techniques. The instrument used in collecting students' creativity data was an observation sheet in the form of scoring. The data obtained were statistically analyzed with the n-gain test to find out how much the improvement of students' creativity, the independent sample $t$ test to find out the difference in the average of the experimental and control classes and the paired sample $t$ test to find out the effectiveness of the increase in student creativity in the experimental class

\section{RESULTS AND DISCUSSION}

This research data in the form of mastery learning and student creativity data obtained from test scores and student observation sheets of the experimental class and the control class. The creativity developed by students of class $\mathrm{X}$ vocational school majoring in computer network engineering is to make a video of Chemsong, a video that contains songs with the theme of learning chemistry, material, atomic structure and the periodic system of elements. A recapitulation of students' classical learning completeness and student creativity on each aspect of creativity is presented in Table 1.

Table 1. Recapitulation of students' classical learning completeness

\begin{tabular}{lllll}
\hline Statistic & \multicolumn{3}{l}{ Learning Completeness } \\
\cline { 2 - 5 } & Pretest & & Posttest & \\
\cline { 2 - 5 } & Eksperiment & Control & Eksperiment & Control \\
\hline Average & 46,67 & 48,13 & 75,47 & 64,41 \\
Top score & 70,00 & 70,00 & 94,00 & 77,00 \\
Lowest score & 30,00 & 25,00 & 50,00 & 47,00 \\
Learning Completeness (\%) & $5,5 \%$ & $9,37 \%$ & $83 \%$ & $50 \%$ \\
\hline
\end{tabular}

Increased mastery learning was analyzed by the N-Gain normalization formula. This test was conducted to determine the magnitude of improvement in classical learning completeness before and after treatment. The results of the Ngain mastery learning based on pretest-posttest data in the experimental and control classes are presented in Table 2.

Tabel 2. N-gain Test Results Classical Students Learning Completeness

\begin{tabular}{lllll}
\hline Class & Pretest & Posttest & N-Gain & Category \\
\hline Control & 48,13 & 64,41 & 0,31 & medium \\
Eksperiment & 46,67 & 75,47 & 0,54 & medium \\
\hline
\end{tabular}

Analytical results of the average $\mathrm{N}$-gain mastery learning in the experimental class is 0.52 with the medium category. Of the 72 students who received high $\mathrm{N}$-gain as many as 20 students while the medium category was 50 students and the low category was 2 students. In the control class classically the $\mathrm{N}$-gain value is 0.31 with the low category. Of the 36 students who obtained moderate $\mathrm{N}$-gain criteria, 14 were students, the low category was 22 students while the high category was absent. The experimental and control class has the $\mathrm{N}$-gain category equation that is medium, but if seen from the $\mathrm{N}$-gain value the experimental class gets a higher value than the control class. This is because in the experimental class there is a very high average difference 
between pretest and posttest. In addition to the $\mathrm{N}$ gain test in this study, a t-test was also conducted to determine the average difference and increase students' learning completeness between the experimental class and the control class.
The difference in the average value and the improvement of students' learning completeness based on the pretest-posttest data and $\mathrm{N}$-gain of the experimental and control classes can be seen in Table 3.

Tabel 3. Classical learning completeness T-test results

\begin{tabular}{llllll}
\hline Average Value & Control & Eksperiment & t count & sig 5\% & Information \\
\hline Pretest & 48,13 & 46,67 & 0,57 & 1,98 & Not Significant \\
Posttest & 64,41 & 75,47 & 4,56 & 1,98 & Significant \\
\hline
\end{tabular}

Table 3. shows that the pretest scores of the control and experimental classes show insignificant differences. This explains that the mastery learning of the control class and the experimental class do not have significant differences. The data in Table 3 shows a significant difference between the control class and the experimental class after being given a video-based project-based learning treatment in the experimental class and conventional in the control class.

The mastery learning of the experimental class and control class students had a significant difference as shown in Table 3. The mastery learning of the experimental class students who were given project-based learning with chemsong video was higher than the control classes that were given conventional learning assisted by modules. The difference in the mastery learning of the experimental class and the control class is evidenced by the calculation of the independent sample t-test test. The hypothesis proposed in this average difference test shows that the experimental class has better learning completeness compared to the control class. The results obtained from this test are $t$ count of 8.23 and $t$ critics of 2.04 which means that the proposed hypothesis is accepted or the average completeness of chemical learning of students who are given a learning strategy based on chemsong video-assisted learning is better than the class with conventional learning assisted module.

After finding out that there is an average difference between the experimental class and the control class, the researchers then tested the increase in the mastery of pretest and posttest through paired sample t test in the experimental class and the control class based on the pretest and posttest values, which the analysis results are presented in Table 4.

Table 4. Comparison of pretest and posttest data

\begin{tabular}{llllll}
\hline Class & \multicolumn{2}{l}{ Average Value } & N-gain & t count & t tabel \\
\cline { 2 - 4 } & Pretest & Posttest & & & \\
\hline Eksperiment & 46,67 & 75,47 & 0,54 & 19,23 & 1,98 \\
Control & 48,13 & 64,41 & 0,31 & 12,40 & 2,02 \\
\hline
\end{tabular}

Based on the results of statistical analysis, learning completeness data in the experimental class obtained $t$ count $=19.23$ at $5 \%$ error level with $\mathrm{dk} 72-1=71$ obtained $\mathrm{t}$ table $=1.98$. The value of $\mathrm{t}$ arithmetic $>\mathrm{t}$ table which means that there is an average difference between the pretest and posttest which means that there is an influence of the application of project-based learning using the Chemsong video in improving student learning completeness. While in the control class obtained t count $=12.40$ at $5 \%$ error level with $\mathrm{dk} 36-1=35$ obtained t table $=2.02 . \mathrm{T}$ count value $<\mathrm{t}$ table which means there is an average difference between pretest and posttest which means there is an influence of the application of conventional learning in improving student learning completeness.

Student creativity in project-based learning assisted by Chemsong video is observed by using observation sheets of student creativity during the learning process. The observed aspects of creativity include attitudes, thought processes, actions and results/products. Observations on aspects of attitudes, thought processes and actions carried out during 4 meetings while the product/outcome aspect is done once assessment. The results of observations obtained in the experimental class are presented in Figure 1. 


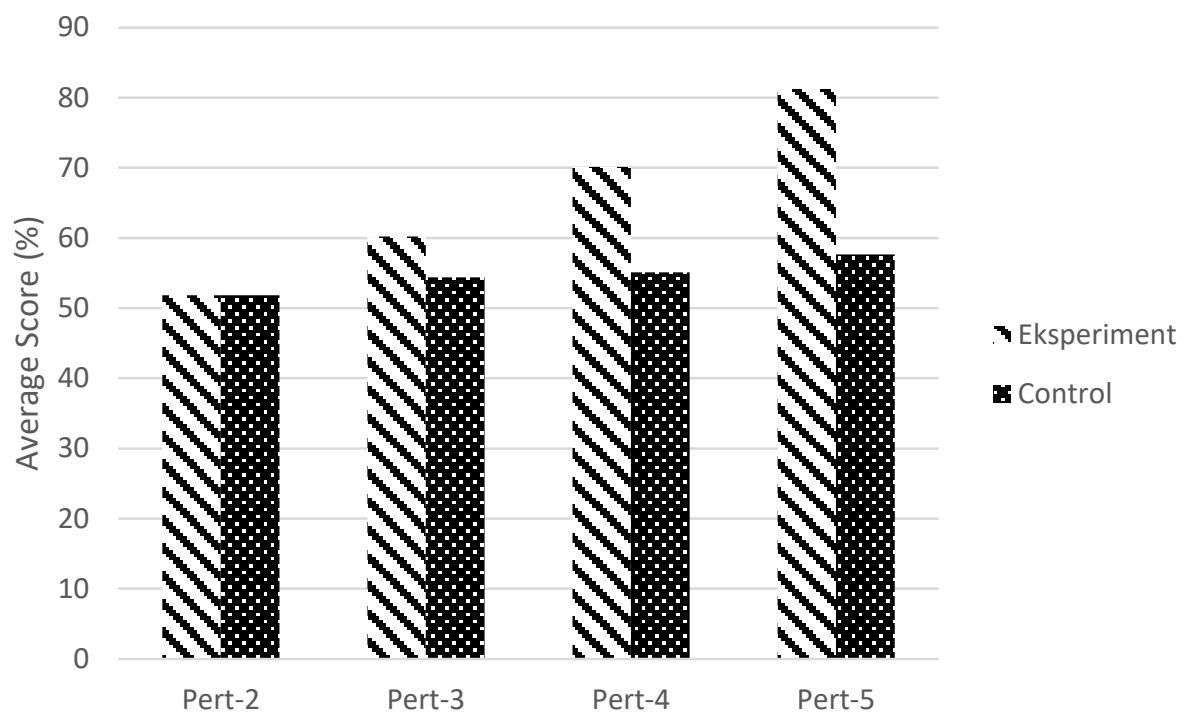

Figure 1. Observation Results of Student Creativity

In this study, creativity measurement uses creativity observation sheets which are carried out during the learning process. The observed creativity is from the aspects of attitude, thought process, actions and products / results. At the beginning of learning, student creativity is considered low because students have never tried to make a project. Creative attitudes, thought processes and actions that give rise to creativity in learning chemistry are also still low from the initial observations made. At the 2nd meeting of the implementation of project-based learning research the average observation score obtained was $51.85 \%$ with less categories.

After the Chemsong video-based projectbased learning in the experimental class the observation of creativity increased with the acquisition of an average score of $60.19 \%$ with a sufficient category at the $3 \mathrm{rd}$ meeting, at the 4 th meeting a mean score of $70.14 \%$ with a sufficient category and at the 5th meeting obtained an average score of $81.25 \%$ in the good or creative category. Whereas in the control class in the 3rd meeting the average score was $54.4 \%$, the 4 th meeting was $55.09 \%$ and in the 5 th meeting was $57.64 \%$. From the acquisition of the mean score of the experimental and control class shows that the creativity of the experimental class is better than the control class.

Mastery learning and student creativity in the experimental group is higher than the control group because in the project-based learning process there are activities to design, make, present the project results and test the results of the project. The student project in this activity is the creation of a video song with the theme of atomic structure and a periodic system of elements called chemsong video. According to Juandi \& Anhar (2017) the use of the PjBL model has an influence on student creativity. The use of the $\mathrm{PjBL}$ model in the teaching and learning process makes it easy for students to understand the material, concepts, providing opportunities for students to express ideas and ideas in constructing their knowledge. Pradita et al. (2015) states that project-based learning (PjBL) can encourage students to increase their creativity through producing products in tangible forms that can increase student creativity. The project based learning (PjBL) model invites students to be active in learning activities while the teacher's role is only as a facilitator and evaluator of products produced by students. In addition, the application of the Chemsong video-assisted model helps student-based learning projects in obtaining information through exploration activities when creating a product. If creativity is combined with learning and technology will produce high quality work. In a recent study showing that technology enables students to build several media that can help them produce high quality work in the context of creativity (Hanif et al., 2019).

Project-based learning in this study requires students to complete certain tasks to be investigated in various ways to complete the task. From these experiences, students can produce 
thinking skills and make them aware that there are alternative ways to solve problems. Learning includes project-based environments in the design and development of mobile applications for students where applications act as educational tools that reflect project-based assignments. Jumaat \& Tasir (2013) concluded in their research that the use of multimedia application projects such as making videos and $2 \mathrm{D}$ animation can build students' knowledge and creativity. O'Shea (2016) said that learning by using video in classroom learning can increase student motivation and enable students to be actively involved in learning.

From the researchers' observations, students are clearly involved in the process of making videos. This is similar to how students can do writing assignments, students appear based on a continuum of quality on the rubric elements of assessment. Students express appreciation for three-level process evaluations such as selfevaluation, peer evaluation, and evaluation of outside experts. According to Spires et al. (2012) project-based learning in the form of video making can be facilitated in the classroom by making space for students to design their own questions and foster a classroom inquiry culture using a combination of print media and multimodal texts. Students are encouraged to find content from multiplying sources and then critically and accurately evaluate so that individual students 'interests and knowledge about content and video production can build on students' strengths and talents.

\section{CONCLUSION}

Based on the research results, it can be concluded that project-based learning with the help of Chemsong videos can improve student learning completeness and creativity as indicated by the results of $\mathrm{N}$-gain and t-test. Based on the independent sample t-test showed that there was a significant difference between the creativity of the control group and the experimental group while based on the paired sample t-test, the value of sig. (2-tailed) $<0.05$ which shows that project-based learning has a positive effect on student mastery learning and creativity. The Chemsong videobased project-based learning model can be applied to chemistry learning in order to provide variety of learning and is also expected to be able to have a positive impact on improving students' classical learning completeness.

\section{REFERENCES}

Al-Oweidi, A. (2013). Creative Characteristics and Its Relation to Achievement and School Type among Jordanian Students. Creative Education, 4(01), 29-30

Andyawati, N. D. M. S. (2011). Pembelejaran Berbasis Proyek Untuk Meningkatkan Kreativitas Dan Hasil Belajar. JPP Undiksha, 44(1), 52-59

Ardianti, S. D., Pratiwi, I. A., \& Kanzunnudin, M. (2017). Implementasi Project Based Learning (PjBL) Berpendekatan Science Edutainment Terhadap Kreativitas Peserta Didik. Refleksi Edukatika: Jurnal Ilmiah Kependidikan, 7(2), 146149

Bell, S. (2010). Project-Based Learning For The 21st Century: Skills For The Future. The Clearing House, 83(2), 39-43.

Dariman, K. (2019). Students' Creative Thinking With 4'R Applications in Procedure Text Project Based Learning. International Journal for Educational and Vocational Studies, 1(1), 15-20.

Hanif, S., Wijaya, A. F. C., \& Winarno, N. (2019). Enhancing Students' Creativity Through STEM Project-Based Learning. Journal of Science Learning, 2(2), 50-57.

Hidayah, A., Yulianto, A., \& Marwoto, P. (2015). Effect of Project Based Learning Approach Contextual To Creativity of Student of Madrasah. In International Conference on Mathematics, Science, and Education in UNNES [Semarang State University) in Central Java, Indonesia. Available online also at: http://icmseunnes. com/2015/wpcontent/uploads/2016/03/73_PE. pdf [accessed in Sidoarjo, East Java, Indonesia: December 14, 2017], 16-20

Hsieh, H. Y., Lou, S. J., \& Shih, R. C. (2013). Applying Blended Learning With Creative Project-Based Learning: A Case Study Of Wrapping Design Course For Vocational High School Students. TOJSAT, 3(3), 49-58.

Jumaat, N. F. \& Tasir, Z. (2013). Integrating Project Based Learning Environment Into The Design And Development Of Mobile Apps For Learning 2D-Animation. Procedia-Social and Behavioral Sciences, 103, 526-533.

Juandi, T. \& Anhar. (2017). Pengaruh Model Pembelajaran Project Based Learning Ditinjau dari Kreativitas Siswa Terhadap Prestasi 
Belajar. Kappa Journal. e-ISSN 2450-2590, 1 (1), 47-52

Lestari, R. A., Hadisaputro, S., \& Nuswowati, M. (2015). Pembelajaran Berbasis Proyek dengan Produk Artikel Untuk Meningkatkan Hasil Belajar Siswa. Chemistry in Education, 4(2), 1521.

Lou, S. J., Chung, C. C., Dzan, W. Y., \& Shih, R. C. (2012). Construction of a creative instructional design model using blended, project-based learning for college students. Creative Education, 3(07), 1281-1290

Munakata, M. \& Vaidya, A. (2015). Using Project-And Theme-Based Learning To Encourage Creativity In Science. Journal of College Science Teaching, 45(2), 48-53.

Munandar, U. (2014). Pengembangan Kreativitas Anak Berbakat. Jakarta: Rineka Cipta.

O'Shea, M. (2016). Engage Students' Creativity Through Animated Whiteboard Video Project. Tech Directions, 75(9), 17-19

Pradita, Y., Mulyani, B., \& Redjeki, T. (2015). Penerapan Model Pembelajaran Project Based Learning Untuk Meningkatkan Prestasi Belajar Dan Kreativitas Siswa Pada Materi Pokok Sistem Koloid Kelas XI IPA Semester Genap Madrasah Aliyah Negeri Klaten Tahun
Pelajaran 2013/2014. Jurnal pendidikan kimia, 4(1), 89-96.

Sari, D. N. A., Rusilowati, A., \& Nuswowati, M. (2017). Pengaruh Pembelajaran Berbasis Proyek terhadap Kemampuan Literasi Sains Siswa. PSEJ (Pancasakti Science Education Journal), 2(2), 114-124.

Spires, H. A., Hervey, L. G., Morris, G., \& Stelpflug, C. (2012). Energizing Project-Based Inquiry: Middle-Grade Students Read, Write, And Create Videos. Journal of Adolescent \& Adult Literacy, 55(6), 483-493.

Sumarni, W. (2015). The Strengths And Weaknesses Of The Implementation Of Project Based Learning: A review. International Journal of Science and Research, 4(3), 478-484.

Tseng, K.H, Chang, C.C., Lou, S.J., \& Chen, W.P. (2013). Attitudes Towards Science, Technology, Engineering and Mathematics (STEM) in A Project-Based Learning (Pjbl) Environment. International Journal of Technology and Design Education, 23(1), 87-102.

Wahida, F. (2015). Pengaruh Model Pembelajaran Berbasis Proyek Terhadap Keterampilan Berpikir Kreatif Dan Hasil Belajar Siswa Kelas X SMA Negeri 1 Parigi. JSTT, 4(3), 25-42. 